This document is the Accepted Manuscript version of a Published Work that appeared in final form in Organic Letters, copyright (C) American Chemical Society after peer review and technical editing by the publisher.

To access the final edited and published work see https://pubs.acs.org/doi/10.1021/acs.orglett.8b03135 


\title{
The One-Pot Synthesis of Dihalogenated Ring-Fused Benzimidazolequinones from 3,6-Dimethoxy-2-(cycloamino)anilines using Hydrogen Peroxide and Hydrohalic Acid
}

\author{
Martin Sweeney, ${ }^{\dagger}$ Lee-Ann J. Keane, ${ }^{\dagger}$ Michael Gurry, ${ }^{\dagger}$ Patrick McArdle ${ }^{\dagger}$ and Fawaz Aldabbagh*,†,‡ \\ ${ }^{\dagger}$ School of Chemistry, National University of Ireland Galway, University Road, Galway, H91 TK33, Ireland \\ ‡ Department of Pharmacy, School of Life Sciences, Pharmacy \& Chemistry, Kingston University, Penrhyn Road, Kingston \\ upon Thames, KT1 2EE, United Kingdom
}

ABSTRACT: 3,6-Dimethoxy-2-(cycloamino)anilines undergo 4- or 6-electron oxidations to afford novel ring-fused halogenated benzimidazoles or benzimidazolequinones using $\mathrm{H}_{2} \mathrm{O}_{2} / \mathrm{HCl}$ or $\mathrm{H}_{2} \mathrm{O}_{2} / \mathrm{HBr} \mathrm{Cl}_{2}$ and $\mathrm{Br}_{2}$ are capable of the same oxidative transformation to the benzimidazolequinones. Labelling experiments indicate that water is necessary for oxidation of the para-dimethoxybenzenes to the corresponding quinones.

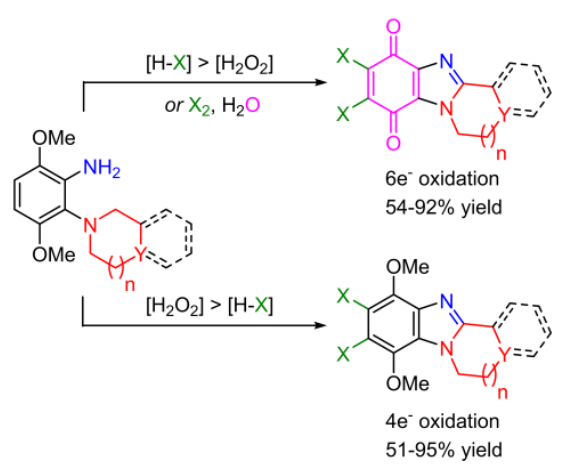

The cleanest method of generating elemental chlorine and bromine in situ is to mix hydrogen peroxide with excess hydrochloric and hydrobromic acid respectively, since the only byproduct is water (Scheme 1). ${ }^{1,2}$ The intermediate is hypohalous acid (HOX), which is commonly used to disinfect water. The molecular halogen $\left(\mathrm{X}_{2}\right)$ in water is in equilibrium with an acidic (HX) solution of $\mathrm{HOX}^{3,4}$

\section{Scheme 1. Generation of $\mathrm{X}_{2}$ from $\mathrm{H}_{2} \mathrm{O}_{2} / \mathrm{HX}$}

$$
\begin{aligned}
& \mathrm{H}_{2} \mathrm{O}_{2}+\mathrm{HX} \longrightarrow \mathrm{HOX}+\mathrm{H}_{2} \mathrm{O} \\
& \mathrm{HOX}+\mathrm{HX} \rightleftharpoons \mathrm{X}_{2}+\mathrm{H}_{2} \mathrm{O}
\end{aligned}
$$

The HOX solution has been used in the electrophilic halogenation of many aromatics. ${ }^{2,5-8}$ On the other hand, $\mathrm{H}_{2} \mathrm{O}_{2}$ in trifluoroacetic acid (TFA) has traditionally been used to give ring-fused benzimidazoles from $o$-cyclic amine substituted anilines. ${ }^{9}$ Recently, methanesulfonic acid (0.5-1 equiv) has replaced TFA in $\mathrm{H}_{2} \mathrm{O}_{2}$ mediated cyclizations to give alicyclic ring-fused benzimidazoles. ${ }^{10}$ In comparison, the $\mathrm{H}_{2} \mathrm{O}_{2} / \mathrm{HX}$ system is relatively underutilized in the synthesis of heterocycles with $\mathrm{H}_{2} \mathrm{O}_{2} / \mathrm{HBr}$ used to catalyze the aziridination of alkenes with chloramine T. ${ }^{11}$ One-pot $\mathrm{H}_{2} \mathrm{O}_{2} / \mathrm{HX}$ mediated oxidative cyclization of $o$-cyclic amine substituted anilines with selective dichlorination and dibromination gave a series of five to eight-membered ring-fused benzimidazoles, generally in $>80 \%$ yield (Scheme 2a). ${ }^{8}$

Scheme 2. $\mathrm{H}_{2} \mathrm{O}_{2} / \mathrm{HX}$ in the Preparation of Benzimidazoles and Benzimidazolequinones (a) Previous one-pot oxidative cyclization:
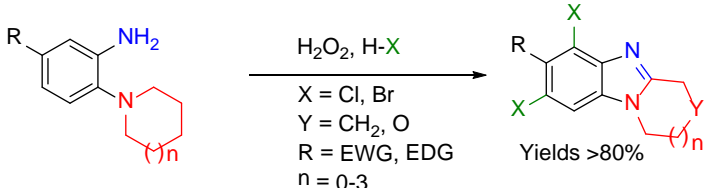

(b) This work:

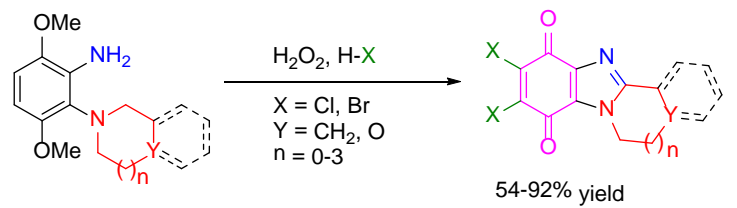

Skibo and co-workers popularized aziridinyl-substituted pyrrolo[1,2-a]benzimidazolequinones as bioreductive antitumor alternatives to the mitomycins, ${ }^{12}$ and other groups reported benzimidazolequinones with useful cytotoxicity, ${ }^{13-21}$ including specificity towards hypoxic tumor cells, ${ }^{18} \mathrm{NAD}(\mathrm{P}) \mathrm{H}$ :quinone oxidoreductase 1 (NQO1) ${ }^{19}$ and Fanconi anemia cells. ${ }^{20,21}$

When para-dimethoxybenzenes are precursors, a two-step $\mathrm{HBr}-$ mediated demethylation to the hydroquinone followed by $\mathrm{FeCl}_{3}$ mediated oxidation is used to give the benzimidazolequinone. ${ }^{10,14,18,19}$ One step conversion of paradimethoxybenzenes to the desired quinones has been effected with $\mathrm{AgO},{ }^{22} \mathrm{Ce}\left(\mathrm{NH}_{4}\right)_{2}\left(\mathrm{NO}_{3}\right)_{6}(\mathrm{CAN}),{ }^{13,23-25} \mathrm{CoF}_{3},{ }^{26} \mathrm{NBS}$ with a catalytic amount of $\mathrm{H}_{2} \mathrm{SO}_{4},{ }^{20,27}$ and $\mathrm{PhI}\left(\mathrm{OCOCF}_{3}\right)_{2}$ (PIFA) ${ }^{28}$ For one-step formation of quinones, $\mathrm{H}_{2} \mathrm{O}_{2} / \mathrm{HX}$ has advantages of high atom economy $^{29}$ and low cost. The simultaneous halogenation on the aromatic or the quinone can be useful for further nucleophilic aromatic substitution ${ }^{14,15,30,31}$ and transition metal-catalyzed crosscouplings, ${ }^{32,33}$ with the resultant functionalization significantly altering biological activity. ${ }^{14,15,21,30,31,33}$ There are reports of low to moderate yields of oxidative demethylation with dihalogenation giving 5,6-dichloro- and 5,6-dibromobenzimidazolequinones using aqua regia $\left(\mathrm{HNO}_{3} / \mathrm{HCl}(1: 3)\right)^{15,16}$ and $\mathrm{HBr} / \mathrm{NaBrO}_{3}$, respectively. ${ }^{16}$ However, the combination of 2-electron oxidation to the quinone with 4-electron oxidative cyclization in one-pot is unknown. Herein, we utilize $\mathrm{H}_{2} \mathrm{O}_{2} / \mathrm{HX}$ to carry out oxidative cyclization, aromatic 
halogenation, and oxidative demethylation to give a new series of ring-fused dihalogenated benzimidazolequinones in mostly high yields (Scheme 2b). In all but one system, the protocol is tunable by adjusting the $\left[\mathrm{H}_{2} \mathrm{O}_{2}\right]$ to $[\mathrm{HX}]$ ratio with high yields of the dihalogenated ring-fused dimethoxybenzimidazoles obtained when the $\left[\mathrm{H}_{2} \mathrm{O}_{2}\right]$ is higher. Furthermore, the halogenation is selective to the activated aromatic or quinone moiety when an additional fused aromatic ring is in place.

Initially, 3,6-dimethoxy-2-(cycloamino)anilines 1a-1e were treated with higher amounts of $\mathrm{H}_{2} \mathrm{O}_{2}$ (10 equiv) relative to $\mathrm{HX}$ (5 equiv) to give, in mostly high yields and without the need for chromatography, novel ring-fused dimethoxy-substituted benzimidazoles via a 4-electron oxidative cyclization and dihalogenation (Scheme 3). 2-(Pyrrolidin-1-yl)aniline 1a and 2(piperidin-1-yl)aniline $\mathbf{1 b}$ were found to be consumed within $20 \mathrm{~min}$ in MeCN under reflux to give dichlorinated and dibrominated pyrrolo[1,2-a]benzimidazoles (2a, $3 \mathbf{3 a})$ and pyrido[1,2a]benzimidazoles (2b, 3b) in yields of $\mathbf{8 0 - 9 2 \%}$ (Scheme 3). For cyclizations of morpholine 1c, azepane 1d and azocane 1e using $\mathrm{H}_{2} \mathrm{O}_{2} / \mathrm{HCl}$, some oxidation to the benzimidazolequinone was detected at reflux. [1,4]Oxazino[4,3-a]benzimidazole 2c, azepino[1,2-a]benzimidazole 2d, and azocino[1,2-a]benzimidazole 2e were selectively formed in good to high yields (67-95\%) by lowering the reaction temperature (from reflux to $40{ }^{\circ} \mathrm{C}$ or rt) and increasing the reaction time (from $20 \mathrm{~min}$ to $2-24 \mathrm{~h}$ ). Benzimidazolequinone formation was not detected in the $\mathrm{HBr}$ mediated cyclizations of 1c, $\mathbf{1 d}$ and $\mathbf{1 e}$ at reflux, with 3c obtained in $89 \%$ yield, while a $6 \mathrm{~h}$ reaction time afforded complete dibromination to give $\mathbf{3 d}$ and $\mathbf{3 e}$ in excellent yield (92 and 95\%, respectively). X-ray crystal structures for the eight-membered dichlorinated and dibrominated adducts $2 \mathbf{e}$ and $\mathbf{3 e}$ were obtained due to similarities of respective NMR spectra.

The utility of the $\mathrm{H}_{2} \mathrm{O}_{2} / \mathrm{HX}$-mediated system was investigated using the more challenging 2-(3,4-dihydroisoquinolin-2(1H)-yl)3,6-dimethoxyaniline (THIQ substrate) 1f with potential for halogenation on the additional aromatic ring (Scheme 3). Upon treatment of $\mathbf{1 f}(0.07 \mathrm{M}$ in $\mathrm{MeCN})$ with $\mathrm{H}_{2} \mathrm{O}_{2}$ (10 equiv) and $\mathrm{HBr}(5$ equiv) at reflux for $20 \mathrm{~min}$, oxidative cyclization was observed at the benzylic position to afford $\mathbf{3 f}$ in $73 \%$ yield. The isolation of dichlorinated analogue $2 \mathbf{f}$ proved challenging under the same conditions due to the greater reactivity of the $\mathrm{H}_{2} \mathrm{O}_{2} / \mathrm{HCl}$ system. The $\mathrm{H}_{2} \mathrm{O}_{2} / \mathrm{HCl}$ system could be tuned to deliver mono- or dichlorination. At room temperature and a $4.5 \mathrm{~h}$ reaction time, only monochlorination was observed, affording $\mathbf{4 f}$ in $60 \%$ yield, while reaction for $24 \mathrm{~h}$ afforded the dichlorinated product $\mathbf{2 f}$ in $51 \%$ yield. The site of monochlorination was confirmed by X-ray crystallography on $\mathbf{4 f}$.

Scheme 3. Synthesis of Dihalogenated Benzimidazoles using $\mathbf{H}_{2} \mathbf{O}_{2} / \mathbf{H X}^{a, b}$

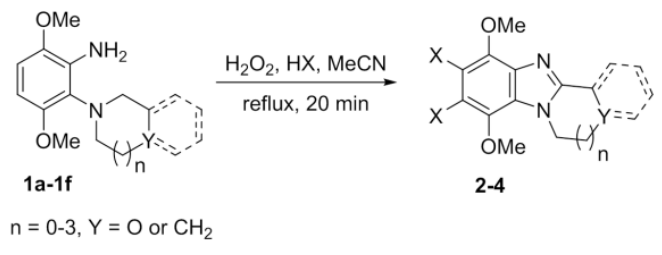

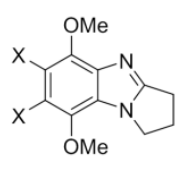

2a, $\mathrm{X}=\mathrm{Cl}, 80 \%$

3a, $\mathrm{X}=\mathrm{Br}, 88 \%$

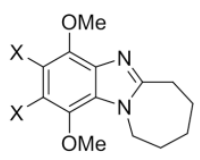

2d, $\mathrm{X}=\mathrm{Cl}, 89 \%^{d}$

3d, $\mathrm{X}=\mathrm{Br}, 92 \%^{f}$

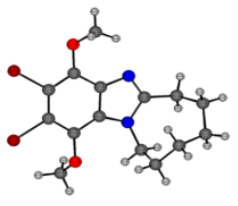

$3 e$

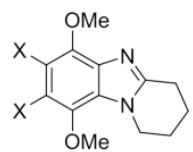

2b, $\mathrm{X}=\mathrm{Cl}, 83 \%$ 3b, $\mathrm{X}=\mathrm{Br}, 92 \%$

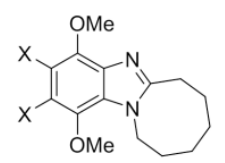

2e, $\mathrm{X}=\mathrm{Cl}, 95 \%^{\mathrm{e}}$ 3e, $\mathrm{X}=\mathrm{Br}, 95 \%^{f}$

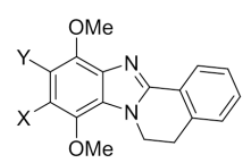

2f, $\mathrm{X}, \mathrm{Y}=\mathrm{Cl}, 51 \%^{g}$

4f, $X=\mathrm{Cl}, Y=\mathrm{H}, 60 \%$

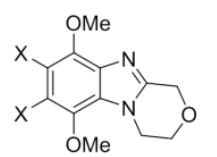

2c, $\mathrm{X}=\mathrm{Cl}, 67 \%^{\mathrm{C}}$ 3c, $\mathrm{X}=\mathrm{Br}, 89 \%$

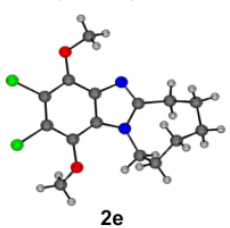

$2 e$

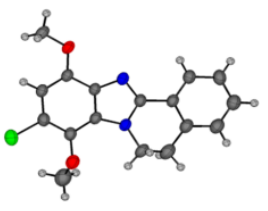

$4 f$
${ }^{a}$ Conditions: 1a-1f $(1.0 \mathrm{mmol}), \mathrm{H}_{2} \mathrm{O}_{2}(10 \mathrm{mmol}), \mathrm{HX}(5 \mathrm{mmol})$, MeCN (10 mL). ${ }^{b}$ Isolated yields. ${ }^{c} 2 \mathrm{~h}, 40^{\circ} \mathrm{C} .{ }^{d} 24 \mathrm{~h}$, rt. ${ }^{e} 5 \mathrm{~h}, 40^{\circ} \mathrm{C}$. f6 h. ${ }^{g} \mathrm{MeCN}$ (15 mL), $24 \mathrm{~h}, \mathrm{rt} .{ }^{h} \mathrm{MeCN}$ (15 mL). ${ }^{i} \mathrm{MeCN}$ (15 mL), $4.5 \mathrm{~h}$, rt. X-ray crystal structures showing one of the two molecules in the asymmetric unit cell for $\mathbf{2 e}$ and $3 \mathbf{e}$ with thermal ellipsoids set at $40 \%$ probability (Figures S1 \& S2), and for $\mathbf{4 f}$ thermal ellipsoids set at $40 \%$ probability.

The room temperature reaction allowed reaction profiling by HPLC (Figure 1) with mass spectrometry detection of chlorinated aniline intermediate 1g, suggesting that chlorination of $\mathbf{1 f}$ occurs prior to oxidative cyclization. This observation may explain the selectivity, of other one-pot oxidative cyclizations to benzimidazoles with aromatic halogenations, ${ }^{8}$ which can now be assumed to be a consequence of the $\mathrm{NH}_{2}$ of the substrate strongly directing the initial electrophilic aromatic substitution. 


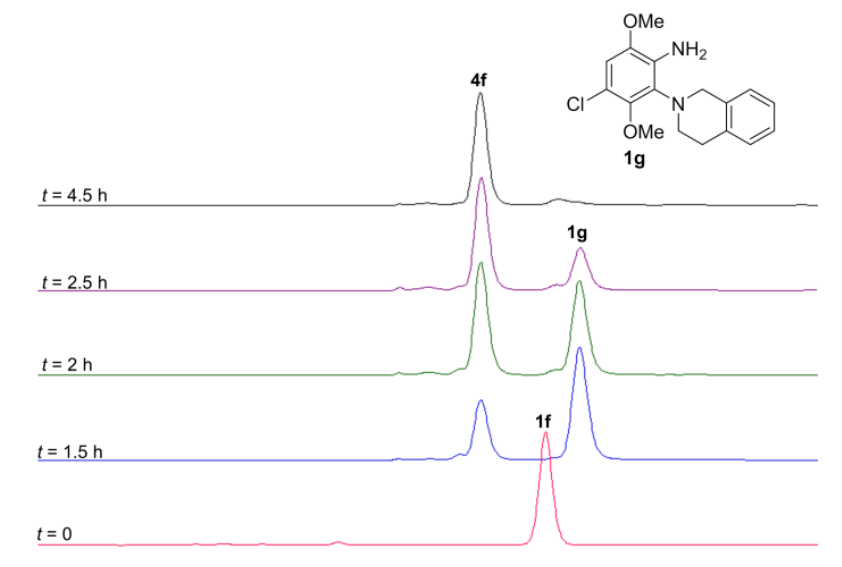

Figure 1. HPLC chromatograms as a function of time $(t)$ for the reaction of 2-(3,4-dihydroisoquinolin-2(1H)-yl)-3,6dimethoxyaniline (1f) with $\mathrm{H}_{2} \mathrm{O}_{2}$ (10 equiv) and $\mathrm{HCl}$ (5 equiv) in MeCN (15 mL) at rt. ESI HRMS (Figure S3) was used to detect 4chloro-2-(3,4-dihydroisoquinolin-2(1H)-yl)-3,6-dimethoxyaniline (1g).

To carry out the one-pot overall 6-electron oxidation, to afford dihalogenated quinones, conditions which favor $\mathrm{X}_{2}$ formation were employed (Schemes 1 and 4). $\mathrm{H}_{2} \mathrm{O}_{2}$ (50 equiv) and $\mathrm{HCl}$ (180 equiv) converted anilines 1a-1d into dichlorinated ring-fused

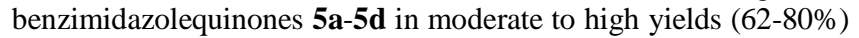
after $4 \mathrm{~h}$ in $\mathrm{MeCN}$ at $80^{\circ} \mathrm{C}$, while 5e was isolated in 54\% yield. For the $\mathrm{H}_{2} \mathrm{O}_{2} / \mathrm{HBr}$-mediated transformations, the high concentrations of $\mathrm{HBr}$ required for quinone formation made it desirable to perform brominations under solvent-free conditions (except for $\mathbf{6 f}$, which necessitated the use of MeCN due to the lower solubility of $\mathbf{1 f}$ in $\mathrm{HBr}$ ). Dibrominated analogues 6a-6e were obtained in high yield (67-92\%) using $\mathrm{H}_{2} \mathrm{O}_{2}$ (60 equiv) in neat $\mathrm{HBr}(30 \mathrm{~mL}$ ) under reflux for $12 \mathrm{~h}$. Ring-fused dihalogenated benzimidazolequinones (Scheme 4) were purified by flash column chromatography with the exception of dibrominated pyrrolo[1,2-a]benzimidazolequinones $\mathbf{6 a}$, which was isolated cleanly without purification. X-ray crystal structures of 7,8-dichloro-3,4-dihydro-1 $H$-[1,4] oxazino[4,3-a]benzimidazole6,9-dione (5c), dichlorinated and dibrominated pyrrolo[1,2a]benzimidazolequinones $\mathbf{5 a}$ and $\mathbf{6 a}$, and azepino[1,2a]benzimidazolequinones $\mathbf{5 d}$ and $\mathbf{6 d}$ were obtained. Isolation of significant amounts of 9,10-dichloro-5,6-dihydrobenzimidazo[2,1a]isoquinoline-8,11-dione (5f) was however not possible by treatment of THIQ $\mathbf{1 f}$ with a high molar ratio of $\mathrm{HCl}$ relative to $\mathrm{H}_{2} \mathrm{O}_{2}$ at reflux. The reaction gave mainly inseparable products with ESI HRMS ( $\mathrm{m} / \mathrm{z}$ 388.9-392.9) indicative of tetrachlorination (Figure S4). This led us to employ the relatively mild conditions of $\mathrm{H}_{2} \mathrm{O}_{2}(10$ equiv) and $\mathrm{HCl}$ (5 equiv) at rt, that allowed aromatic monochloride and dichloride $\mathbf{4 f}$ and $2 \mathbf{f}$ to be isolated in good yields after 4.5 and $24 \mathrm{~h}$, respectively (Scheme 3, Figure 1), with extension to $72 \mathrm{~h}$ giving benzimidazolequinone $\mathbf{5 f}$ in $56 \%$ isolated yield (Scheme 4, Figure S5 for the HPLC chromatographs). The structure of $\mathbf{5 f}$ was confirmed by X-ray crystallography. In contrast the dibrominated analogue $6 \mathbf{f}$ was isolated in $68 \%$ yield from a $7 \mathrm{~h}$ reflux in the presence of a large excess of $\mathrm{HBr}$; overbromination adducts were not detected. This is in line with the greater reactivity of $\mathrm{Cl}_{2}$ relative to $\mathrm{Br} 2$ in electrophilic halogenation reactions. ${ }^{34}$
Scheme 4. Synthesis of Dihalogenated Benzimidazolequinones using $\mathrm{H}_{2} \mathrm{O}_{2} / \mathrm{HX}^{a, b}$

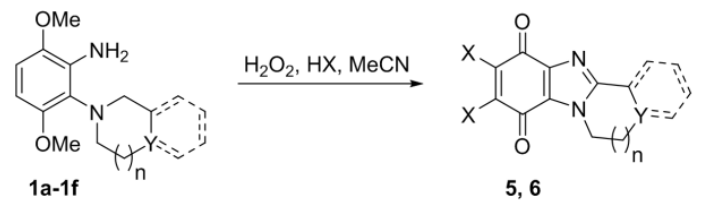

$\mathrm{n}=0-3, \mathrm{Y}=\mathrm{O}$ or $\mathrm{CH}_{2}$

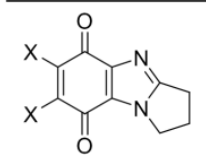

5a, $\mathrm{X}=\mathrm{Cl}, 73 \%$ 6a, $\mathrm{X}=\mathrm{Br}, 81 \%$

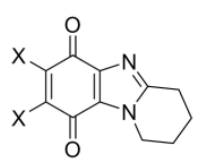

5b, $\mathrm{X}=\mathrm{Cl}, 76 \%$ 6b, $X=B r, 74 \%$

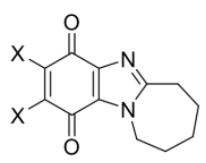

5d, $\mathrm{X}=\mathrm{Cl}, 80 \%$ 6d, $X=B r, 86 \%$

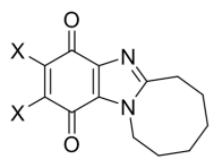

5e, $\mathrm{X}=\mathrm{Cl}, 54 \%$ 6 e, $X=B r, 92 \%$

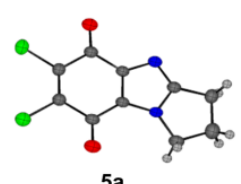

$5 a$

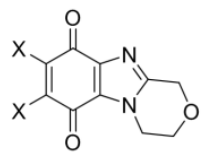

5c, $X=\mathrm{Cl}, 62 \%$

6c, $X=B r, 67 \%$

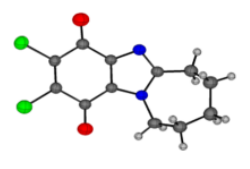

$5 d$

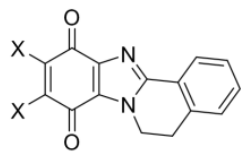

5f, $\mathrm{X}=\mathrm{Cl}, 56 \%^{\mathrm{c}}$ 6f, $X=B r, 68 \%^{d}$

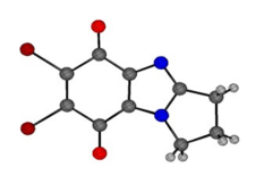

6a

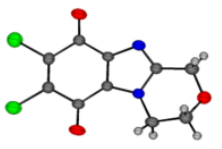

$5 c$

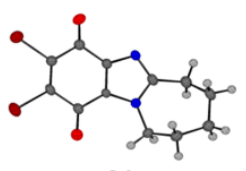

$6 d$

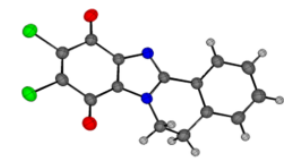

$5 f$
${ }^{a}$ Conditions: For the synthesis of dichlorides 5a-5e: 1a-1e $(1.0$ mmol), $\mathrm{H}_{2} \mathrm{O}_{2}$ (50 mmol), $\mathrm{HCl}(180 \mathrm{mmol}), \mathrm{MeCN}$ (10 mL), 4 h, 80 ${ }^{\circ} \mathrm{C}$. For the synthesis of dibromides 6a-6f: 1a-1f (1.0 mmol), $\mathrm{H}_{2} \mathrm{O}_{2}$ (60 mmol), $\mathrm{HBr}(30 \mathrm{~mL}), 12 \mathrm{~h}$, reflux. ${ }^{b}$ Isolated yields. ${ }^{c} \mathrm{H}_{2} \mathrm{O}_{2}(10$ mmol), $\mathrm{HCl}$ (5 mmol), MeCN (15 mL), $72 \mathrm{~h}, \mathrm{rt} .{ }^{d} \mathrm{HBr}(135 \mathrm{mmol})$, MeCN (15 mL), 7h. X-ray crystal structures shown of 5a, 5c, 5d, 5f, 6a, and 6d have thermal ellipsoids set at $40 \%$ probability. Crystal structure of $\mathbf{6 a}$ is one of the six molecules in the asymmetric unit cell (Figure S6).

Due to the suspected high concentration of $\mathrm{Cl}_{2}$ or $\mathrm{Br}_{2}$ in the onepot 6-electron oxidative cyclizations with dihalogenation, we decided to investigate if the formation of ring-fused dihalogenated benzimidazolequinones could be effected by elemental $\mathrm{X}_{2}$, with or without water. Chlorine gas was bubbled into a solution of anilines 1b-1e in MeCN containing added $\mathrm{H}_{2} \mathrm{O}$ (Table 1). Dichlorinated benzimidazolequinones $\mathbf{5 b}$, 5c and $\mathbf{5 d}$ were isolated, but in lower yields in comparison to $\mathrm{H}_{2} \mathrm{O}_{2} / \mathrm{HCl}$ method, although $5 \mathbf{e}$ was given in a comparable yield of $58 \%$ in this 10 min reflux reaction. A comparative study, using $1 \mathbf{c}$ and $\mathrm{Cl}_{2}$ was carried out in an equivalent amount of water $\left(10.75 \mathrm{~mL}\right.$ ) to the $\mathrm{H}_{2} \mathrm{O}_{2} / \mathrm{HCl}$ protocol, however the yield of 5 c was decreased further from $54 \%$ to $47 \%$. Thus, water is required but not to the extent of the $\mathrm{H}_{2} \mathrm{O}_{2} / \mathrm{HCl}$ method. Moreover, yields deteriorated when the $\mathrm{Cl}_{2}$ reaction was performed under anhydrous conditions with inseparable products given. Over- 
chlorination of 1-methylnapthalene was observed by Johnson et al. when $\mathrm{Cl}_{2}$ was used under aprotic conditions. ${ }^{35}$ Higher yields (71$90 \%$ ) were achieved for the analogous one-pot transformation giving dibrominated benzimidazolequinones $\mathbf{6 b}, \mathbf{6 d}$ and $\mathbf{6 e}$ using $\mathrm{Br} 2$ and $\mathrm{H}_{2} \mathrm{O}$ at $40{ }^{\circ} \mathrm{C}$ for $4 \mathrm{~h}$, which is indicative of the greater control achieved with less reactive $\mathrm{Br}_{2}$ (that is not susceptible to further bromination).

Table 1. Synthesis of Dihalogenated Benzimidazolequinones using Elemental Chlorine and Bromine ${ }^{a, b}$
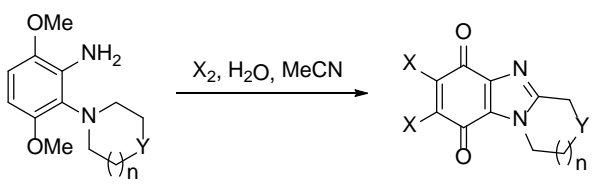

$1 b-1 e$

5,6

\begin{tabular}{ccccc} 
aniline & $\mathrm{X}$ & $\mathrm{Y}$ & $\mathrm{n}$ & yield (\%) \\
\hline $\mathbf{1 b}$ & $\mathrm{Cl}$ & $\mathrm{CH}_{2}$ & 1 & $\mathbf{5 b}, 41$ \\
$\mathbf{1 c}$ & $\mathrm{Cl}$ & $\mathrm{O}$ & 1 & $\mathbf{5 c}, 54$ \\
$\mathbf{1 c}$ & $\mathrm{Cl}$ & $\mathrm{O}$ & 1 & $\mathbf{5 c}, 47^{c}$ \\
$\mathbf{1 d}$ & $\mathrm{Cl}$ & $\mathrm{CH}_{2}$ & 2 & $\mathbf{5 d}, 71$ \\
$\mathbf{1 e}$ & $\mathrm{Cl}$ & $\mathrm{CH}_{2}$ & 3 & $\mathbf{5 e}, 58$ \\
$\mathbf{1 b}$ & $\mathrm{Br}$ & $\mathrm{CH}_{2}$ & 1 & $\mathbf{6 b}, 71$ \\
$\mathbf{1 d}$ & $\mathrm{Br}$ & $\mathrm{CH}_{2}$ & 2 & $\mathbf{6 d}, 90$ \\
$\mathbf{1 e}$ & $\mathrm{Br}$ & $\mathrm{CH}_{2}$ & 3 & $\mathbf{6 e}, 90$
\end{tabular}

${ }^{a}$ Conditions: For synthesis of dichlorides: 1 (1.0 mmol), $\mathrm{Cl}_{2}$ (50.0 mmol), $\mathrm{H}_{2} \mathrm{O}$ (1.8 mL), MeCN (10 mL), reflux, $10 \mathrm{~min}$. For synthesis of dibromides: 1 (1.0 mmol), $\mathrm{Br}_{2}$ (50 mmol), $\mathrm{H}_{2} \mathrm{O}$ (1.8 $\mathrm{mL}), \mathrm{MeCN}(10 \mathrm{~mL}), 40{ }^{\circ} \mathrm{C}, 4 \mathrm{~h} .{ }^{b}$ Isolated yields. ${ }^{c} \mathrm{H}_{2} \mathrm{O}(10.75 \mathrm{~mL})$.

Finally we investigated the role of water in the quinone formation step. 7,8-Dihalo-6,9-dimethoxybenzimidazoles 2c and 3b were respectively treated with $\mathrm{Cl}_{2}$ and $\mathrm{Br}_{2}$ (both 50 equiv), and $\mathrm{H}_{2}{ }^{18} \mathrm{O}$ (100 equiv) in MeCN (Scheme 5). The formation of the doubly ${ }^{18} \mathrm{O}$-labelled dihalogenated benzimidazolquinones $7 \mathbf{c}$ and 8b was confirmed by EI-MS (Figure S7 \& S8). It follows that for both the $\mathrm{Cl}_{2}$ and $\mathrm{Br}_{2}$-mediated reactions, $\mathrm{MeO}$-aryl bond cleavage occurred, and quinone formation did not proceed through the hydroquinone. A control experiment treating 7,8-dichloro-3,4dihydro- $1 H$ - $[1,4]$ oxazino[4,3- $a$ ]benzimidazole-6,9-dione 5c with $\mathrm{H}_{2}{ }^{18} \mathrm{O}$ for $4 \mathrm{~h}$ indicated no exchange.

In conclusion, $\mathrm{H}_{2} \mathrm{O}_{2} / \mathrm{HX}$ has led to an unprecedented one-pot 6electron oxidative transformation to yield a new series of ring-fused dihalogenated benzimidazolequinones. The elemental halogens $\left(\mathrm{X}_{2}\right)$ generated in situ from $\mathrm{H}_{2} \mathrm{O}_{2} / \mathrm{HX}$ are shown to be the active species in the oxidative synthesis. When a higher molar ratio of $\mathrm{H}_{2} \mathrm{O}_{2}$ relative to $\mathrm{HX}$ is employed, the $\mathrm{X}_{2}$ concentration is lower, and the 4-electron oxidative cyclization is not accompanied by oxidation to the quinone, allowing the selective formation of a new series of ring-fused dihalogenated benzimidazoles.
Scheme 5. Detecting the role of water in Quinone formation with proposed mechanism ${ }^{a}$

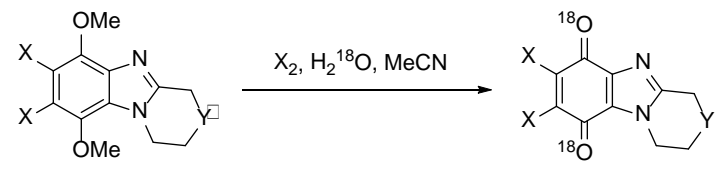

2c, 3b

7c, $\mathrm{X}=\mathrm{Cl}, \mathrm{Y}=\mathrm{O}$

8b, $X=\mathrm{Br}, \mathrm{Y}=\mathrm{CH}_{2}$

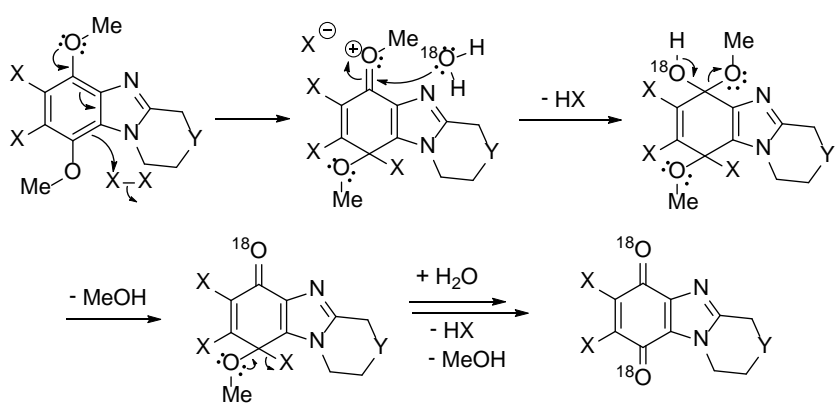

${ }^{a}$ Reaction conditions: For dichloride 7c: $2 c$ (0.07 mmol), $\mathrm{Cl}_{2}$ (3.40 $\mathrm{mmol}), \mathrm{H}_{2}{ }^{18} \mathrm{O}(0.14 \mathrm{~mL})$, dried MeCN $(0.73 \mathrm{~mL})$, reflux, $10 \mathrm{~min}$. For dibromide 8b: $3 \mathbf{b}(0.04 \mathrm{mmol}), \mathrm{Br}_{2}$ (2.05 mmol), $\mathrm{H}_{2}{ }^{18} \mathrm{O}(0.08$ $\mathrm{mL})$, dried $\mathrm{MeCN}(1 \mathrm{~mL}), 40^{\circ} \mathrm{C}, 4 \mathrm{~h}$.

\section{ASSOCIATED CONTENT}

\section{Supporting Information (SI)}

The Supporting Information is available free of charge on the ACS Publications website at DOI: XXXXXXXXXXXX.

SI contains detailed experimental, synthetic procedures, characterization data, NMR spectra and crystallographic data for all new compounds (PDF).

\section{Accession Codes}

CCDC 1863022-1863030 contains the supplementary crystallographic data for this paper. These data can be obtained free of charge via www.ccdc.cam.ac.uk/data_request/cif, or by emailing data_request@ccdc.cam.ac.uk, or by contacting, The Cambridge Crystallographic Data Centre, 12 Union Road, Cambridge CB2 1EZ, UK; fax: +44 1223336033.

\section{AUTHOR INFORMATION}

\section{Corresponding Author}

*E-mail: f.aldabbagh@kingston.ac.uk

\section{ORCID}

Fawaz Aldabbagh: 0000-0001-8356-5258

Notes

The authors declare no competing financial interest. 


\section{ACKNOWLEDGMENTS}

We thank the Irish Research Council (IRC) for a Government of Ireland Postgraduate Scholarship for M. Sweeney and the College of Science, National University of Ireland Galway (NUI Galway) for a Postgraduate Scholarships for L. -A. J. Keane and M. Gurry.

\section{REFERENCES}

(1) Sivey, J. D.; McCullough, C. E.; Roberts, A. L. Environ. Sci. Technol. 2010, 44, 3357-3362.

(2) Ben-Daniel, R.; de Visser, S. P.; Shaik, S.; Neumann, R. J. Am. Chem. Soc. 2003, 125, 12116-12117.

(3) Eigen, M.; Kustin, K. J. Am. Chem. Soc. 1962, 84, 13551361.

(4) Beckwith, R. C.; Wang, T. X.; Margerum, D. W. Inorg. Chem. 1996, 35, 995-1000.

(5) Podgoršek, A.; Zupan, M.; Iskra, J. Angew. Chem. Int. Ed. 2009, 48, 8424-8450.

(6) Mukhopadhyay, S.; Ananthakrishnan, S.; Chandalia, S. B. Org. Process Res. Dev. 1999, 3, 451-454.

(7) Vyas, P. V.; Bhatt, A. K.; Ramachandraiah, G.; Bedekar, A. V. Tetrahedron Lett. 2003, 44, 4085-4088.

(8) Gurry, M.; Sweeney, M.; McArdle, P.; Aldabbagh, F. Org. Lett. 2015, 17, 2856-2859.

(9) Nair, M. D.; Adams, R. J. Am. Chem. Soc. 1961, 83, 35183521.

(10) Sweeney, M.; Gurry, M.; Keane, L. -A. J.; Aldabbagh, F. Tetrahedron Lett. 2017, 58, 3565-3567.

(11) Jain, S. L.; Sharma, V. B.; Sain, B. Tetrahedron Lett. 2004, 45, 8731-8732.

(12) Skibo, E. B.; Jamil, A.; Austin, B.; Hansen, D.; Ghodousi, A. Org. Biomol. Chem. 2010, 8, 1577-1587.

(13) Antonini, I.; Claudi, F.; Cristalli, G.; Franchetti, P.; Grifantini, M.; Martelli, S. J. Med. Chem. 1988, 31, 260264.

(14) Garuti, L.; Roberti, M.; Malagoli, M.; Rossi, T.; Castelli, M. Bioorg. Med. Chem. Lett. 2000, 10, 2193-2195.

(15) Ryu, C. -K.; Song, E. -H.; Shim, J. -Y.; You, H. -J.; Choi, K. U.; Choi, I. H.; Lee, E. Y.; Chae, M. J. Bioorg. Med. Chem. Lett. 2003, 13, 17-20.

(16) Chung, K. -H.; Hong, S. -Y.; You, H. -J.; Park, R. -E.; Ryu, C. -K. Bioorg. Med. Chem. 2006, 14, 5795-5801.

(17) Gellis, A.; Kovacic, H.; Boufatah, N.; Vanelle, P. Eur. J. Med. Chem. 2008, 43, 1858-1864.

(18) Lynch, M.; Hehir, S.; Kavanagh, P.; Leech, D.; O'Shaughnessy, J.; Carty, M. P.; Aldabbagh, F., Chem. Eur. J. 2007, 13, 3218-3226.

(19) Moriarty, E.; Carr, M.; Boham, S.; Carty, M. P.; Aldabbagh, F. Eur. J. Med. Chem. 2010, 45, 3762-3769.

(20) O’Donovan, L.; Carty, M. P.; Aldabbagh, F. Chem. Commun. 2008, 43, 5592-5594.

(21) Fahey, K.; O’Donovan, L.; Carr, M.; Carty, M. P.; Aldabbagh, F. Eur. J. Med. Chem. 2010, 45, 1873-1879.

(22) Snyder, C. D.; Rapoport, H. J. Am. Chem. Soc. 1972, 94, 227-231.

(23) Jacob, P.; Callery, P. S.; Shulgin, A. T.; Castagnoli, N. J. Org. Chem. 1976, 41, 3627-3629.

(24) Joyce, E.; McArdle, P.; Aldabbagh, F. Synlett 2011, 2011, 1097-1100.

(25) Dao, P. D. Q.; Ho, S. L.; Cho, C. S. ACS Omega 2018, 3, 5643-5653.
(26) Tomatsu, A.; Takemura, S.; Hashimoto, K.; Nakata, M. Synlett 1999, 1999, 1474-1476.

(27) Kim, D. W.; Choi, H. Y.; Lee, K. -J.; Chi, D. Y. Org. Lett. 2001, 3, 445-447.

(28) Tohma, H.; Morioka, H.; Harayama, Y.; Hashizume, M.; Kita, Y. Tetrahedron Lett. 2001, 42, 6899-6902.

(29) Trost, B. M. Acc. Chem. Res. 2002, 35, 695-705.

(30) Ibis, C.; Tuyun, A. F.; Bahar, H.; Ayla, S. S.; Stasevych, M. V.; Musyanovych, R. Y.; Komarovska-Porokhnyavets, O.; Novikov, V. Med. Chem. Res. 2014, 23, 2140-2149.

(31) Entwistle, I. D.; Williams, P. J.; Devlin, B. R. J. Certain Benzotriazole-4,7-dione Derivatives. U.S. Patent 3,952,003, April 20, 1976.

(32) Rao, M. L. N.; Giri, S. RSC Adv. 2012, 2, 12739-12750

(33) Louvis, A. d. R.; Silva, N. A. A.; Semaan, F. S.; da Silva, F. d. C.; Saramago, G.; de Souza, L. C. S. V.; Ferreira, B. L. A.; Castro, H. C.; Salles, J. P.; Souza, A. L. A.; Faria, R. X.; Ferreira, V. F.; Martins, D. d. L. New J. Chem. 2016, 40, 7643-7656

(34) Voudrias, E. A.; Reinhard, M. Environ. Sci. Technol. 1988, 22, 1049-1056.

(35) Cum, G.; de la Mare, P. B. D.; Johnson, M. D. J. Chem. Soc. C 1967, 0, 1590-1598. 